J. Lake Sci. (湖泊科学), $2006, \mathbf{1 8}(3): 273-279$

http:// www. jlakes. org. E-mail: jlakes@ niglas. ac.cn

(c) 2006 by Journal of Lake Sciences

\title{
巢湖沉积植硅体组合及中全新世以来的环境演变”
}

\author{
范斌, 许世远, 俞立中, 蒋 辉, 再莉华 \\ (华东师范大学地理信息科学教育部重点实验室,上海 200062)
}

\begin{abstract}
摘 要: 通过巢湖南灵钻孔 (ACN) 的植硅体化石的系统研究, 划分出六个植硅体组合带. 并根据各植硅体组合带主要成 分所反映的生态特征,结合主成分分析法 $(\mathrm{PCA})$, 恢复了该区中全新世以来的古气候与古环境变化: 自 $5600 \mathrm{aBP}$ 以来气 候划分为 3 个相对寒冷期 $(5600-5200 \mathrm{aBP} 、 4600-3600 \mathrm{aBP} 、 2500-2100 \mathrm{aBP}$ ) 和 3 个相对温暖时期 $(5200-4600 \mathrm{aBP}$ 、 $3600-2500 \mathrm{aBP} 、 2100-1800 \mathrm{aBP}$ ); 并讨论了各个时期巢湖流域的环境变化.

关键词: 巢湖;植硅体; 全新世;环境演变

\section{Phytolith in the sediment of the Lake Chaohu since Middle Holocene and its paleoenviron- mental implications}

FAN Bin, XU Shiyuan, YU Lizhong, JIANG Hui \& RAN Linhua

(Key Laboratory of Geographic Information Science of the Ministry of Education, East China Normal University, Shanghai 20062 , P. R. China)

\begin{abstract}
According to systematic research on the phytolith fossils of core Nanlin in the Lake Chaohu, the phytoliths in the area can be divided into six zones. Based on changes in the main components in the phytolith zones and principal components analysis, the evolution of paleoenvironment and paleoclimate since the middle Holocene is reconstructed. There are three cold periods ( $5600-5200 \mathrm{aBP}, 4600-3600 \mathrm{aBP}, 2500-2100 \mathrm{aBP}$ ) and three warm periods ( $5200-4600 \mathrm{aBP}, 3600-2500 \mathrm{aBP}, 2100-1800 \mathrm{aBP}$ ) since $5600 \mathrm{aBP}$. The environment changes of each period in the Lake Chaohu area were discussed compared with other areas.
\end{abstract}

Keywords: Lake Chaohu; phytolith; holocene; environment changes

湖泊沉积物通常是陆地环境千年尺度时间序列环境变化记录的良好载体 ${ }^{[1]}$. 沉积物中的植硅体记录 了历史时期的植物类型、温度、湿度等综合信息,是古生态环境研究的重要手段之一. 不同的沉积物中的植 硅体提供了丰富的环境信息. 波德研究了美国中央平原北部沙丘中植硅体的古气候指示特征 ${ }^{[2]}$. 吕厚远 等通过对现代表层土壤中植硅体的研究, 建立起植物硅酸体组合一气候因子转换函数 ${ }^{[3]}$. 王伟铭等研究 洞穴沉积植硅体的气候指数, 根据指示型植硅体, 建立了温暖指数和干旱指数的模式 ${ }^{[4]}$. 贾继伟通过的湛 江湖光岩玛珥湖植硅体的研究探讨了该区的环境变迁 ${ }^{[5]}$. 顾延生研究了过去 5000 年来鄱阳湖植硅体记录 的古气候和人类活动信息 ${ }^{[6]}$.

研究区巢湖流域地处西太平洋季风区, 是亚热带和暖温带过渡地带, 属副热带季风气候区, 是东部低旋 气候与反气旋气候比较频繁发生的地区, 也是水灾、旱灾等自然灾害比较频繁发生的地区 ${ }^{[7]}$. 针对巢湖流 域生态环境研究中的气候变化问题, 本文通过对南灵号钻孔 (ACN) 沉积物中植硅体的系统研究, 根据植硅 体类型变化, 分析古气候变化规律, 对巢湖流域的环境变迁提出新的证据.

\section{1 研究区概况}

巢湖流域位于安徽省中部 $\left(116^{\circ} 24^{\prime} 30^{\prime \prime}-118^{\circ} 00^{\prime} 00^{\prime \prime} \mathrm{E} 、 30^{\circ} 58^{\prime} 00^{\prime \prime}-32^{\circ} 58^{\prime} 00^{\prime \prime} \mathrm{N}\right)$, 属亚热带和暖温带

* 国家自然科学基金(40271107)资助项目. 2005-07-04 收稿; 2005-09-13 收修改稿. 范斌,男,1971 年生,博士 研究生; E-mail:fanbinsh@163.com. 
过渡性地副热带季风气候区. 气候温和湿润, 年平均温度 $15-16^{\circ} \mathrm{C}, 1$ 月份平均气温 $2-3^{\circ} \mathrm{C}, 7$ 月份平均气 温 $28-30^{\circ} \mathrm{C}$, 极端最高气温 $39.2^{\circ} \mathrm{C}$, 极端最低气温 $-20.6^{\circ} \mathrm{C}$, 无霜期 $224-252 \mathrm{~d}$.

巢湖流域的植被属于属北亚热带北缘类型, 地带性植被为落叶阔叶与常绿阔叶混交林, 木本植物有: 苦 槠(Castanopsis sckerophylla)、(Cinnamomum camphora) 、木荷（Schima superba）、绵槠( Lithocarpus henryi)、 紫楠(Phoebesheareri) 、白栋( Quercus fabri) 、马尾松(Pinus massoniana)、枫香( Liquidambar formosana)、青冈 (Cyclobalanpsis glauca)、化香( Platycarya strobilacea)、麻栋( Quercus acutissima)、黄檀 (Dalbergi ahupeana)、 山合欢 (Albizzi kalkora) 等; 草本植物有: 鹅观草( Roegneria kamoji)、狗尾草( Pennisetum alopecuroides)、白草 (Pennisetum flaccidum)、画眉草( Eragrostis pilosa)、芦苇 (Phargmites communis)、莎草 (Cypeus rotundu)、黄 蒿(Artemisia annua)、地蓼属 (Polygonum aviculare)、车前草(Plantago asinatica)、垂穗苔草( Carex dimorpholepis)、水芹 (Oenanthejavanica $)^{\text {等 }}{ }^{[8]}$.

\section{2 研究材料与方法}

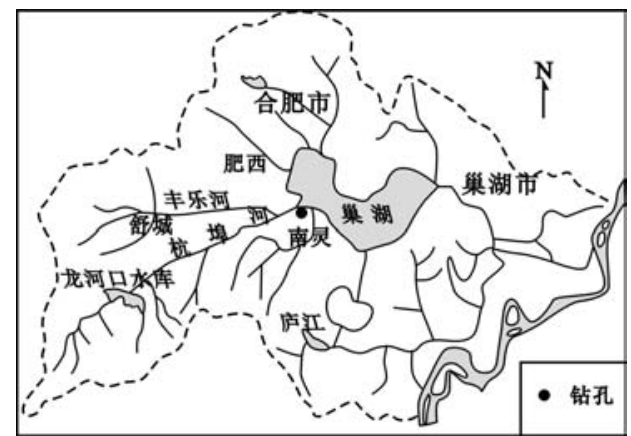

图 1 研究区域和南灵钻孔 (ACN) 位置

Fig. 1 Location of core( ACN) in Lake Chaohu area

南灵钻孔 (ACN) 位于巢湖西岸, 杭埠河人湖处的 灵台圩. 地理坐标为 $31^{\circ} 31^{\prime} 47^{\prime \prime} \mathrm{N}, 117^{\circ} 22^{\prime} 30^{\prime \prime}$ E. 2003 年 7 月 10-15日, 利用钻机对南灵的沉积物进行取样, 共 钻到 $1640 \mathrm{~cm}$ 沉积物, 本文研究其中连续的 $150 \mathrm{~cm}$ 至 $630 \mathrm{~cm}$ 部分. 该柱从 $150 \mathrm{~cm}$ 至 $630 \mathrm{~cm}$ 沉积物大致可以 分为 12 层, 各层深度和岩性特征如下:

第一层 $(150-170 \mathrm{~cm})$ : 浅黄色含细砂质粉砂, 含铁 质和锰质结核; 第二层 $(170-200 \mathrm{~cm})$ : 青灰色粘土, 质 地均一; 第三层 $(200-220 \mathrm{~cm})$ : 浅灰色粉砂, 沉积物中 含有细砂,含铁质结核; 第四层 $(220-230 \mathrm{~cm})$ : 青灰色 粉砂质粘土, 沉积物干结后较硬; 第五层 $(230-260$ $\mathrm{cm})$ : 浅灰色粘土质粉砂,质地均一; 第六层 $(260-280$

$\mathrm{cm})$ : 浅黄色粘土质粉砂, 含铁质和锰质结核; 第七层 $(280-300 \mathrm{~cm})$ : 浅黄色粉砂质粘土, 含铁质和锰质结核; 第八层 $(300-360 \mathrm{~cm})$ : 浅灰色粘土质粉砂, 含细 砂, 细砂成分多为石英; 第九层 $(360-400 \mathrm{~cm})$ : 青灰色粘土, 含植物残片; 第十层 $(400-430 \mathrm{~cm})$ : 青灰色 粘土,含铁质和锰质结核; 第十一层 $(430-460 \mathrm{~cm})$ : 浅灰色粘土,有纹理; 第十二层 $(460-630 \mathrm{~cm})$ : 青灰 色粘土,含铁质和锰质结核, 有纹理.

植硅体采样间隔为 $10 \mathrm{~cm}$, 共采得 49 个样品. 样品分析主要步骤如下: (1) 将干燥样品 (约 $5 \mathrm{~g}$ ) 放人 $15 \mathrm{ml}$ 试管, 加人 $30 \% \mathrm{H}_{2} \mathrm{O}_{2}$, 约 3 倍样品体积, 用玻棒充分混合, 静置 $12-24 \mathrm{~h}$, 将样品放人恒温水浴锅中加 热 $3 \mathrm{~h}$, 并不断搅拌, 使其充分氧化, 倒掉酸溶液, 加蒸馏水离心洗 3 次; (2) 滴人 $15 \%$ 的 $\mathrm{HCl}$, 浸泡 $12-24 \mathrm{~h}$, 倒掉酸溶液, 加蒸馏水离心洗 3 次; (3) 加人比重为 2.38 的镉重液进行离心浮选, 将浮选物移人试管, 加蒸 馏水洗 3 次; (4) 将样品滴到载物片, 用 $\operatorname{Naphrax}(\mathrm{dn}=1.73)$ 固定制成样品薄片.

每个样品在显微镜 (Leica)下统计 2-4 个固定片 $(22 \mathrm{~cm} \times 22 \mathrm{~cm})$ 上所有固定形状的植硅体类型, 它们 多数为禾本科植物的植硅体. 样品中的植硅体含量较为丰富, 样品统计一般都在 $280-320$ 粒之间.

本文采用有序聚类分析划分植硅体组合带, 利用主成分分析 (PCA) 对植硅体数据进行分析, 以揭示植 硅体类型变化特征和阐述各植硅体类型之间的相互关系. 并根据已知各植硅体类型所反映的生态特征, 探 讨各植硅体组合主要成分的变化与古环境变迁的关系.

利用超灵敏小型回旋加速器质谱仪, 对巢湖南灵孔柱样品的有机炭进行加速器质谱法测年, $171 \mathrm{~cm}$ 样 品 (样品号和实验室编号 ACN2) 测年为 $1868 \pm 130 \mathrm{aBP} 、 280 \mathrm{~cm}$ 样品 (ACN5) 的年龄为 $2180 \pm 112 \mathrm{aBP} 、 490$ $\mathrm{cm}$ 样品 (ACN7) 的年龄为 $4907 \pm 122 \mathrm{aBP} 、 990 \mathrm{~cm}$ 样品 (ACN16) 的年龄为 $7472 \pm 144 \mathrm{aBP}$.

\section{3 研究结果}

经鉴定, 南灵钻孔沉积物植硅体类型主要为: 突起扇型、无突起扇型、方型、长方型、棒型、尖型和哑铃型 
等. 吕厚远、王永吉等人通过对中国不同地区土壤中植硅体和现代植物的研究发现: 禾本科不同亚科的植 物, 发育形态完全不同的短细胞植硅体. 湿润环境下生长的禾本科发育哑铃型、扇型、长方形和方型植硅 体; 分布在相对寒冷环境的禾亚科,主要生产齿型、帽型、棒型、尖型植硅体; 画眉草亚科生长在温暖而干旱 的环境, 其代表植硅体为短鞍型; 竹亚科主要分布在热带至亚热带地区, 要求有较高的温度和降水, 长鞍型 植硅体为竹亚科的典型代表; 水稻亚科生产典型的水稻扇型和稻壳单峰或双峰植硅体, 同时产生的哑铃型 植硅体 ${ }^{[9]}$.

根据钻孔沉积物植硅体主要类型的数量变化, 可以将本孔植硅体自下而上划分为 6 个组合带 (图 2).

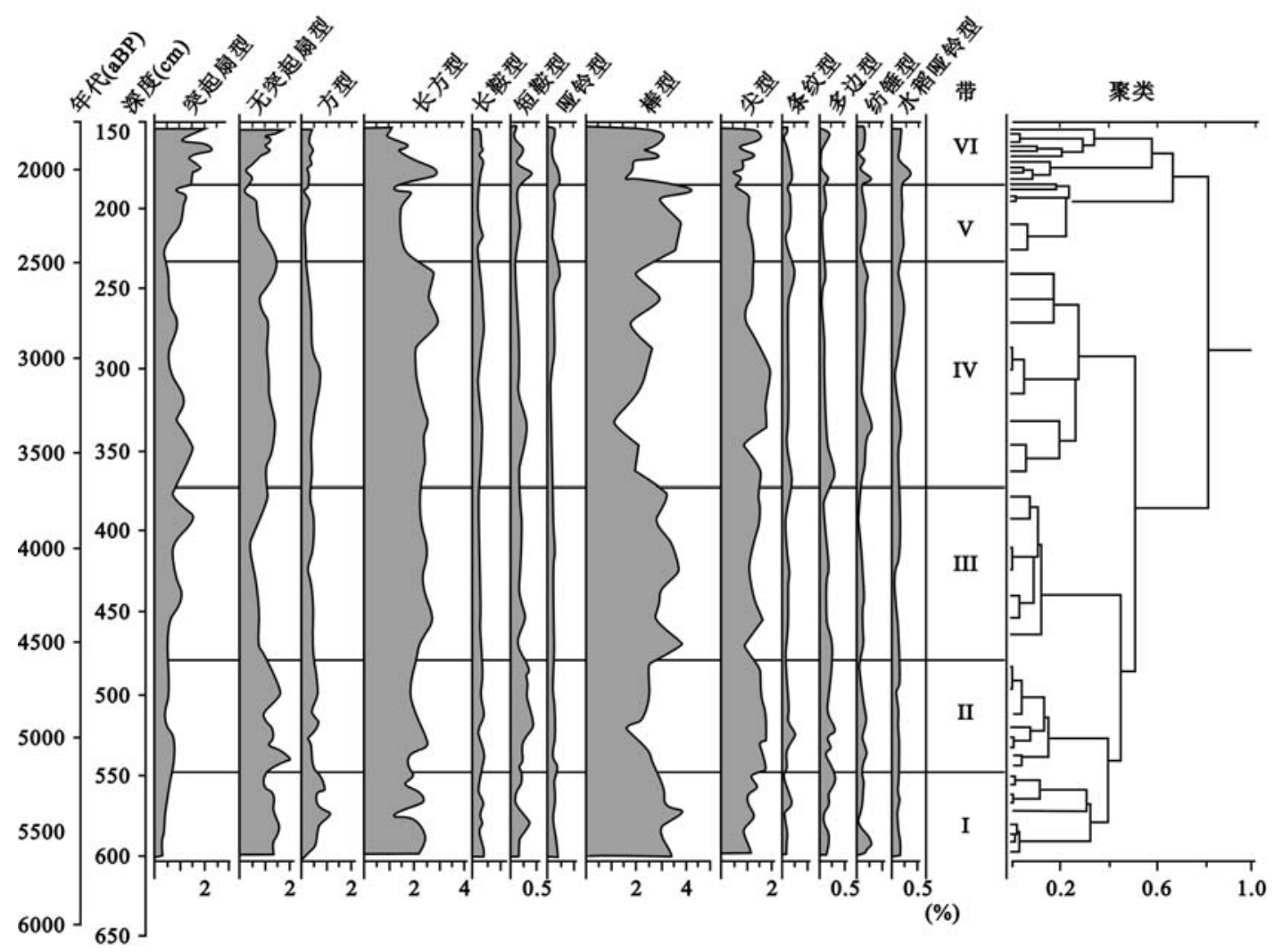

图 2 巢湖南灵钻孔 ( ACN) 植硅体含量分布图

Fig. 2 Percentage diagram of phytolith from the ACN, Lake Chaohu

组合带 ( I ) :5600 - 5200 aBP (630 - 555 cm). 植硅体的含量丰富, 反映寒冷气候特征的棒型 $(29 \%-$ $35 \%)$ 和尖型 $(9 \%-15 \%)$ 大量出现; 其他常见成分包括反映温暖气候特征的长方型 $(20 \%-23 \%)$ 、无突起 扇型 $(12 \%-14 \%)$ 、突起扇型 $(3.4 \%-5.2 \%) 、$ 长鞍型 $(1.0 \%-2.7 \%) 、$ 哑铃型 $(1.2 \%-3.1 \%) 、$ 水稻哑铃 型 $(1.2 \%-2.6 \%)$; 反映温暖干旱气候特征的短鞍型( $1.0 \%-5.5 \%)$; 有少量木本植物植硅体 (多边型、树 枝型、纺锤型) 出现. 本带气候为相对寒冷期.

组合带 ( II ) :5200 - 4600 aBP (555-465 cm). 植硅体的含量较丰富, 反映温暖气候特征的长方型、无突 起扇型、突起扇型含量增加,长方型一般在 21\%-23\%,无突起扇型一般在 $13 \%-19 \%$ 、突起扇型一般在 4\%-6\% ; 反映寒冷气候特征的棒型和尖型含量减少; 其他成分包括突起哑铃型、短鞍型、水稻哑铃型和木 本植物植硅体含量变化较小. 本带气候为相对温暖期.

组合带 ( III ) :4600 - 3600 aBP (465-390 cm) . 反映寒冷气候特征的棒型和尖型含量增加, 棒型含量一 般在 $27 \%-34 \%$ 左右,尖型一般在 $11 \%-14 \%$ 左右; 反映温暖气候特征的长方型、无突起扇型、突起扇型的 
含量减少;方型、长鞍型、短鞍型、水稻哑铃型含量较少. 本带气候为相对寒冷期.

组合带 (IV) : $3600-2500 \mathrm{aBP}(390-295 \mathrm{~cm})$. 反映温暖气候特征的长方型、无突起扇型含量增加, 长 方型含量一般在 20\%-28\% 左右,无突起扇型一般在 10\%-13\% ; 反映寒冷气候特征的棒型和尖型含量减 少. 本带气候为相对温暖期.

组合带 $(\mathrm{V}): 2500-2100 \mathrm{aBP}(295-255 \mathrm{~cm})$. 反映寒冷气候特征的棒型植硅体和尖型植硅体含量增 加,棒型含量一般在 $29 \%-36 \%$, 尖型一般在 $9 \%-11 \%$; 反映温暖气候特征的长方型、无突起扇型、突起扇 型的含量减少. 本带气候为相对寒冷期.

组合带 $(\mathrm{VI}): 2100-1800 \mathrm{aBP}(255-150 \mathrm{~cm})$. 反映温暖气候特征的植硅体含量增加, 长方型含量一般 在 $20 \%-28 \%$, 无突起扇型一般在 10\%-13\% ; 反映寒冷气候特征的棒型和尖型植硅体含量减少; 哑铃型、 长鞍型、短鞍型和木本植物植硅体含量变化不明显. 植硅体总特征反映了气候变暖的趋势.
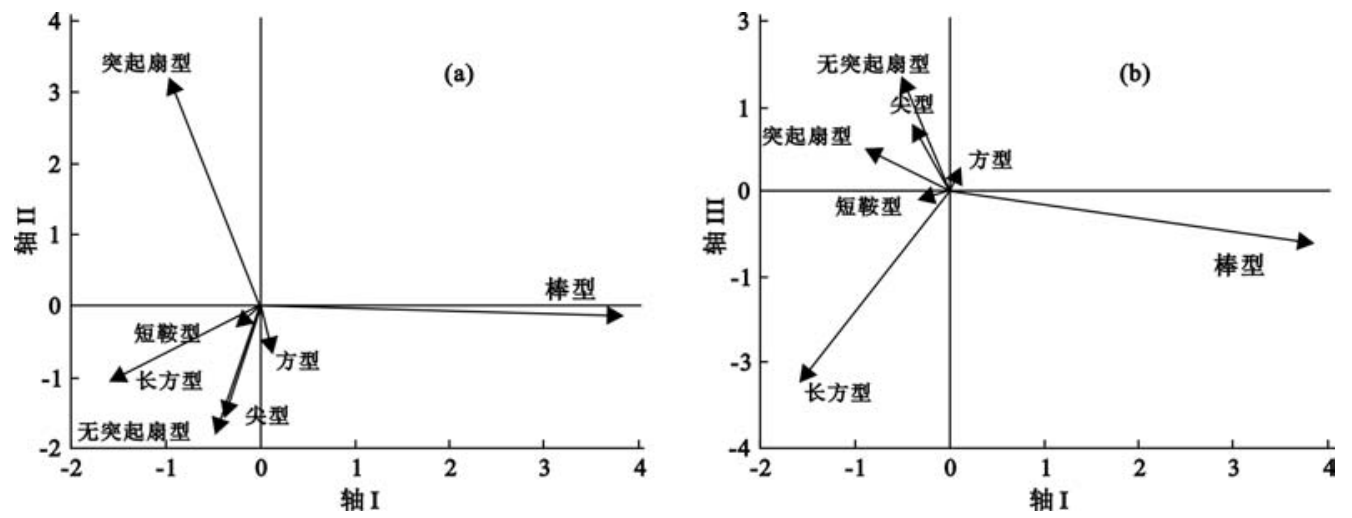

图 3 巢湖南灵孔主要植硅体类型关系图

( $a$ 为主要植硅体类型在数轴 I 和 II 的分布; $b$ 为在数轴 I 和 III 的分布)

Fig. 3 Relationships of the main phytolith species, Lake Chaohu

本文用主成分分析法对巢湖南灵孔植硅体的数量变化及其相互之间的关系进行了探讨 (图 3 ). 最初 的 3 个数轴解释了 $80 \%$ 的植硅体组合中的成分变化,分别为 $40 \% 、 24 \%$ 和 $16 \%$. 图 3 中,植硅体类型由矢 量代表, 矢量的长短与植硅体类型的数量呈正比, 箭头方向指向其极值. 植硅体类型之间的相互关系由矢 量间夹角大小表示: 夹角小于 $90^{\circ}$ 为正相关, 夹角越小, 关系越密切; 夹角大于 $90^{\circ}$ 小于 $180^{\circ}$ 为负相关; 若其 夹角近似 $90^{\circ}$, 则两植硅体类型之间基本上无直接联系 ${ }^{[10]}$. 棒型植硅体与轴 $\mathrm{I}$ 呈正相关 (图 $3 \mathrm{a}, 3 \mathrm{~b}$ ), 而突起 扇型 (图 3b) 与长方型、短鞍型 (图 3a,3b) I 轴呈负相关. 如前所述, 棒型植硅体与分布在相对寒冷环境的 禾亚科关系密切, 突起扇型、长方型和短鞍型则与分布在相对温暖和/或湿润环境的植物相关. 因此, 轴 I 可 被近似的看作为 “温度” 数轴, 其正值方向代表气候相对寒冷,负值方向代表气候相对温暖. 轴 II 和轴 III 的 古环境意义尚不清楚, 因为在图 3a 中, 指示相对温暖和/或湿润环境的突起扇型与轴 II 呈正相关, 而与其呈 负相关的既有指示相对温暖和/或湿润环境的方型和无突起扇型, 又包括指示相对寒冷环境的尖型; 在图 $3 \mathrm{~b}$ 中, 与轴 III 呈正相关的既有指示相对温暖和/或湿润环境的方型、突起扇型和无突起扇型, 又包括指示 相对寒冷环境的尖型. 另外, 仅仅是轴 I 就解释了 $40 \%$ 的植硅体组合中的成分变化. 因此,巢湖南灵孔植硅 体样品在轴 I 的得分值,可间接地指示本地区气候与环境的变化(图 4).

由图 4 可见,自 $5600 \mathrm{aBP}$ 以来,巢湖流域气候经历了 3 个相对寒冷 $(5600-5200 \mathrm{aBP} ; 4600-3600 \mathrm{aBP}$; $2500-2100 \mathrm{aBP}$ ) 期和 3 个相对温暖时期( $5200-4600 \mathrm{aBP} ; 3600-2500 \mathrm{aBP} ; 2100-1800 \mathrm{aBP}$ ), 与用有序 聚类分析划分的植硅体组合带结果相吻合. 在相对寒冷时期,植硅体组合是以反映寒冷气候成分的棒型较 为丰富; 而在气候相对较为温暖期, 扇型、长方形和方形植硅体含量较高 (图 3,4 ). 


\section{4 区域对比与问题讨论}

$5600-5200 \mathrm{aBP}$ 巢湖流域处在一个气候相对寒冷的时期,气候波动较明显, 冷锋的时间大致在 5500 $\mathrm{aBP} .5500 \mathrm{aBP}$ 前后的降温事件在中国较为明显, 在不同的地区其峰值出现的时间有所不同. 上海地区 $5600-5300 \mathrm{aBP}$ 为寒冷气候时期,海面下降 4-5 $\mathrm{m}^{[11]}$; 杭嘉湖平原的狍粉研究也表明低温值的高峰大约发 生在 $5445 \mathrm{aBP}{ }^{[12]}$; 余姚河姆渡遗址狍粉组合显示 $5600 \mathrm{aBP}$ 气温有明显的下降，亚 热带常绿阔叶林收缩，温带森林成分增加 ${ }^{[13]}$; 内蒙古察素齐 $5390-5160 \mathrm{aBP}$ 期 间, 地层中缺失花粉, 代表一段对植物生长极为不利的干旱而又偏冷的气候 ${ }^{[14]}$; 青藏高原的祁连山敦德冰芯 $5400 \mathrm{aBP}$ 温度降至 8000 年以来的最低点 ${ }^{[15]}$; 藏东南 仁错、海登湖高分辨率狍粉一气候转换函数计算出 $5300 \mathrm{aBP}$ 前后年降雨量、年均温 均有较大幅度下降, $5300 \mathrm{aBP}$ 前, 孢粉组合中松、桦木较多, 形成针阔混交林, 其 后，松、桦木减少，草甸开始出现 ${ }^{[16]}$; 乌鲁木齐河源冰川 $5700 \mathrm{aBP}$ 有一次冰进，当 时降温幅度达 $11.5^{\circ} \mathrm{C}$, 是全新世该处冰川前进中降温幅度最大的一次 ${ }^{[17]}$; 洱海碳 同位素和硅藻组合同时显示 $5300 \mathrm{aBP}$ 时段有一个气候的冷干阶段 ${ }^{[18]}$; 这次降温 事件在考古学上称为仰韶中期的寒冷期 ${ }^{[19-20]}$. 另外, 水稻哑铃型植硅体的发现 记录了巢湖流域种植水稻的历史起码可以追溯到 $5600 \mathrm{aBP}$,但其时代比浙江河姆 渡和河南贾湖要晚一些, 可能比张玉兰等 ${ }^{[21]}$ 研究过的广富林遗址和肖家仪等 ${ }^{[22]}$ 研究的苏州龙南遗址文化层发现的稻粒 (据测定为 $5000 \mathrm{aBP}$ ) 的年代要早.

$5200-4600 \mathrm{aBP}$ 巢湖流域是总体显示温暖,其中有波动的特征的气候. 上海 地区良渚文化早期 (5200-4700 aBP) 孢粉组合以木本花粉为主, 总数达 $40 \%-$ $46.8 \%$, 草本花粉其次, 为 $31.4 \%-35.7 \%$. 木本花粉中以常绿阔叶的青岗栎、栲 属为主. 草本花粉以水生草本为主, 其中以香蒲含量最多, 花粉的特征反映温暖湿 润的气 ${ }^{[1]}$. 黄土高原的马家窑文化时期 (5000-4000 aBP) 黄土高原气候较温暖 湿润,水作农业发达 ${ }^{[23]}$.

$4600-3600 \mathrm{aBP}$ 巢湖流域是一个气候较为寒冷的时期, 冷锋的时间大致在 $4500 \mathrm{aBP} .4600$ - 4200 aBP 红原 (青藏高原东北边缘) 泥炭记录了一次非常寒冷的 事件 ${ }^{[24]} .4600 \mathrm{aBP}$ 在日本海发生了黑潮减弱, 变冷事件 ${ }^{[25]}$; 金川泥炭 $\delta^{18} \mathrm{O}$ 记录记 录了 $4600 \mathrm{aBP}$ 降温事件 ${ }^{[26]}$; 敦德冰芯的记录了 $4600 \mathrm{aB} . \mathrm{P}$ 气候变冷事件 ${ }^{[15]}$; 洪业 汤等认为: $4600 \mathrm{aB} . \mathrm{P}$ 气候变冷的事件,对应北美洲与欧洲的中全新世气候变冷的

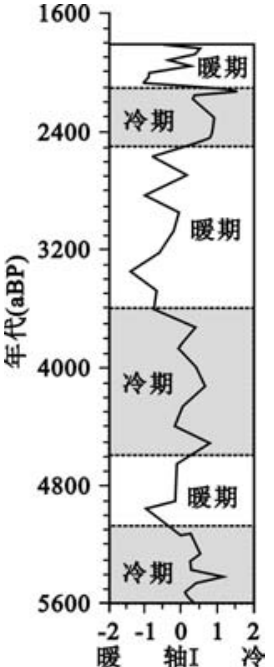

图 4 巢湖地区近 5600 年以来古气

候变化示意图

Fig. 4 Diagram of paleoclaimatic changes of Lake

Chaohu area since

$5600 \mathrm{aBP}$ 事件,与敦德冰芯同一时期记录到的冷峰对应 ${ }^{[26]}$. 欧洲的阿尔卑斯地区在 $4800-4500 \mathrm{aBP}$ 期间存在一次 明显的气候变冷事件,该期间世界各个地区发生了类似的事件 ${ }^{[27]}$; 寒冷的气候导致美索布达亚平原北部居 民点遗弃,印度和流域和埃及文明发生崩溃 ${ }^{[28]}$ 。

$3600-2500 \mathrm{aBP}$ 巢湖流域是总体显示温暖, 其中有气候波动的特征比较显著. 龙感湖 $3200-2400 \mathrm{aBP}$ 孢粉浓度较高, 阔叶乔木树种花粉丰富, 总体显示为温湿阶段 ${ }^{[29]}$. 3900-3250 aBP 上海马桥地区为温暖湿 润得气候,年平均气温比现在高 $2^{\circ} \mathrm{C}$, 为第二次洪水期,且为高海面 ${ }^{[30]} .3300 \mathrm{aBP}$ 河南商代古都殷墟甲骨文 记载安阳盆地见有大象和孔雀 ${ }^{[31]}$. 甲骨文中卜雨的卜辞占甲骨文卜辞的 $1 / 5$, 记载了有雨可种植农作物的 月份,识别论证了商代气温偏高, 殷墟时代气候温和,年平均温度高于当代 $2^{\circ} \mathrm{C}^{[32]}$.

$2500-2100 \mathrm{aBP}$ 巢湖流域的气候相对较冷, 上海马桥地区在 $2450-2000 \mathrm{aBP}$ 也为干冷的气候 ${ }^{[31]}$. 龙 感湖 2400-2000 aBP 叶绿素衍生物 (CD)、类胡夢卜素 ( TC) 、蓝藻叶黄素 (Myx) 含量明显降低, 水生、湿生 草本植物减少, 反映气候变冷 ${ }^{[29]}$.

$2100-1800 \mathrm{aBP}$ 巢湖流域的气候转暖. 苏家岗发掘出距今 2000 多年前的人类住宅区, 墓地和垃圾堆 放场, 发现诸多动物骨头, 特别是鹿骨、鹿角数量较多, 巢湖流域当时的气候比较温暖 ${ }^{[33]}$. 龙感湖 $2000-$ $1600 \mathrm{aBP}$ 各种色素含量增高, 花粉中暖性木本属种相应增多,表明气候变暖的趋势 ${ }^{[29]}$. 


\section{5 结论}

(1) 根据巢湖植硅体组合成分的变化, 自下而上可划分为 6 个植硅体组合带. 其中, 奇数带以反映气 候寒冷的植硅体类型数量较多为特征.

(2) 用主成分分析法对巢湖南灵孔植硅体类型的数量变化及其相互关系研究表明, 代表寒气候的冷 棒型植硅体与轴 I 呈正相关 (图 3a,3b), 而代表温暖气候突起扇型、长方型、短鞍型与轴 I 呈负相关. 因此, 巢湖南灵孔植硅体样品在轴 I 的得分值, 可间接地指示本地区气候与环境的变化. 据此, 可将巢湖流域自 $5600 \mathrm{a}$ BP 以来气候划分为 3 个相对寒冷期 (5600-5200 aBP、4600-3600 aBP 、2500-2100 aBP ) 和 3 个相 对温暖时期 (5200 - 4600 aBP、3600-2500 aBP、2100-1800 aBP ).

(3) 巢湖流域植硅体研究所记录到的自 $5600 \mathrm{aBP}$ 以来的基本气候变化,可以和东部一些地区典型剖 面气候事件相对比, 不仅丰富了该地区古气候与古环境变化记录, 证实我国东部气候变化的一致性, 而且进 一步证明了植硅体化石是研究古气候与古环境变化的有效手段之一.

致谢: 北京大学、兰州大学、中科院上海应用物理研究所进行了样品测年, 在植硅体的鉴定过程中, 得到了中 科院地质与地球物理所吕厚远研究员和南京古生物所王伟铭研究员的帮助, 笔者特此致以衰心的感谢!

\section{6 参考文献}

１１］王苏民.张振克. 中国湖泊沉积与环境演变研究的新进展. 科学通报, 1999,44(6):579-587.

[2] Boyd, M. Phytoliths as paleoenvironmental indicators in a dune field on the northern Great Plains. Journal of Arid Environments, 2005,61(3):357 - 375 .

[3] Lu Houyuan, Wu Naiqin, Yang Xiangdong, et al. Phytoliths as quantitative indicators for the reconstruction of past environmental conditions in China I: Phytolith-based transfer function. Quaternary Science Reviews, 2005 (待).

[4]王伟铭, 刘金陵, 周晓丹. 南京直立人洞穴沉积植硅体气候指数研究. 科学通报, 2003,48(1):1205 -1208 .

[5] 贾继伟. 湛江湖光岩玛 $55 \mathrm{ka}$ 以来植硅体化石记录及其古环境变迁. 中国科学院地质与地球物理研究 所硕士论文,2004:1-35.

[6] 顾延生. 长江中游钻孔沉积物记录的 5000 年来气候变化与环境重建 [学位论文]. 武汉大学, 2004:1 -100 .

[7] 张秀丽, 郭品文,阿金海. 1991 年夏季长江中下游降水和风场的低频振荡特征分析. 南京气象学院学 报, $2002,25(3): 388-394$.

[8] 巢湖志编纂委员会编. 巢湖志. 合肥:黄山出版社, 1989:1-24.

[9]吕厚远, 王永吉. 晚更新世以来洛川黑木沟黄土地层中植物硅酸体研究及古植物演替. 第四纪研究, $1991,1: 72-84$.

[10] 蒋 辉, 吕厚远, 支崇远等. 硅藻分析与第四纪定量古地理和古气候研究. 第四纪研究, 2002,22(2): $113-122$.

[11] 王开发,张玉兰,封卫青.上海地区全新世植被,环境演替与古人类活动关系探讨. 海洋地质与第四纪 地质, 1996,16(3): 1 -4.

[12] 施少华. 全新世高温期环境变化对太湖流域新石器文化的影响. 湖泊科学, 1993,5(2):136-143.

[13] 孙湘君,杜乃秋, 陈明洪. "河姆渡" 先人生活时期的古植被古气候. 植物学报,1981,23(2):146 - 215 .

[14] 王 瑜, 宋长青,程全国等. 利用花粉 - 气候响应面恢复查素齐泥炭剖面全新世古气候的尝试. 植物 学报, 1998,40 (11): $1067-1074$.

[15] 姚檀栋, Thompson L G, 施雅风等. 古里雅冰芯中末次间冰期以来气候变化记录研究. 中国科学 (D), $1997,27(5): 447-452$.

[16] 唐领余, 沈才明, 廖淦标等. 西藏两个小湖高分辨率的狍粉记录. 植物学报, 1999,41(8):896-902. 
[17] 陈吉阳. 天山乌鲁木齐河源全新世冰川变化的地衣年代学等若干问题之初步研究. 中国科学 (B 辑), 1988 , (2) : 95 - 104.

[18] 张振克,吴瑞金,王苏民等. 全新世大暖期云南洱海环境变化的湖泊沉积记录. 海洋与湖沼, 2000,31 (2) $: 210-214$.

[19] 吕厚远. 新石器以来的北温带草原文化与气候变迁. 文物保护与考古科学, 1991,3(2):44-50.

[20] 刘东生, 吴文祥. 全新世中期气候转变在中国古代文明起源中的可能作用. 中国社会科学院古代文明 研究中心通讯, 2003,5(5):23-30.

[21] 张玉兰,张敏斌, 宋建. 从广富林遗址中的植硅体组合特征看先民农耕发展. 科学通报,2003,48(1):96 -99 .

[22] 肖家仪. 水稻的植物蛋白石及其考古学意义. 环境考古研究 (第一辑), 北京: 科学出版社, 1991:218 -220 .

[23] An Cheng-Bang, Tang Lingyu, Barton Loukas et al. Climate change and cultural response around 4000 cal yr BP in the western part of Chinese Loess Plateau. Quaternary Research,2005,63(3):347 - 352 .

[24] 徐海,洪业汤,林庆华等. 红原泥炭纤维素氧同位素指示的距今 $6 \mathrm{ka}$ 温度变化. 科学通报, 2002,47 (15) : $1181-1186$.

[25] 翦知湝, 孟 竡. 长江口区全新世古环境变化及其对黑潮变得的响应. 海洋地质与第四纪地质,2002, $22(3): 77-82$.

[26] 洪业汤,姜洪波,陶发祥等. 近 $5 \mathrm{ka}$ 温度的金川泥炭 $\delta 180$ 记录. 中国科学 ( D 辑), 1997,27 (6) :525 -530 .

[27] Baroni C, Orom Belli G. The Alpine" Iceman" and Holocene climate change. Quaternary Research, 1996,46 (1) $: 78-86$.

[28] Weisss H, Courty M A, Wtterstrom W, et al. The genies and collapse of third-millenni north Mesopotamian civilization. Science, 1996,261:948 - 955.

[29] 敗文川, 吴瑞金, 羊向东等. 龙感湖地区近 3000 年来的气候环境变迁. 湖泊科学, 1998,10(2):37 - 43 .

[30] 张 芸, 朱 诚, 史 威. 上海马桥地区全新世中晚期气候变化、海面变化和古洪水. 海洋科学, 2002, 16( 1) :54 - 58 .

[31] 计宏详. 中国全新世大暖期哺乳动物与气候波动. 海洋地质和第四纪地质, 1996,16(1):5-16.

[32] 胡厚宣.气候变迁雨现代气候之探讨. 民国丛书. 甲骨文商史论丛二集. 上海: 上海书店. 1990:1-64.

[33] http://www. ahhs. gov. cn/ly/dedyz. htm. 